\title{
Scleroderma with Rash and Clubbing - A Case Report
}

\author{
Major L A S Abdul-Aziz \\ $M B, C h B, M R C P I, R A M C$ \\ Consultant Physician \\ BMH Rinteln BIPO 29
}

\section{Introduction}

Skin in scleroderma can be affected with or without systemic involvement. Lesions have been described as localized, generalized, or linear morphoea'. The patient described had clubbing and guttate depigmented plaques. Acquired clubbing has not been described previously, but guttate lesions have!

\section{Case History}

A 24 year old previously healthy, Jamaican-born man presented with a ninc-month history of half a stone weight loss, gencral malaise, inability to pass the army basic fitness test due to shortness of breath, skin rash and Raynaud's phenomenon.

There was no history of previous illness, in particular there was no pulmonary disease, exposure to industrial material, infectious diseases or chronic diarrhoea. Therc was no history of clubbing in the family.

On examination, there was clubbing, multiple splinter haemorrhages in the proximal nail folds and taut, shiny distal digital skin (Fig 1). The upper part of the body was covered with multiple, one contimetre diameter depigmented plaques (Fig 2). There was no lymphadenopathy or hepatosplenomegaly, heart sounds were normal, and direct questioning elicited dysphagia.

\section{Investigations}

The following were abnormal:-

ESR $55 \mathrm{~mm} / 1 \mathrm{st} \mathrm{hr}$, antinuclear factor (diffuse pattern titre 1 in 640). Endoscopy showed mild duodenitis with

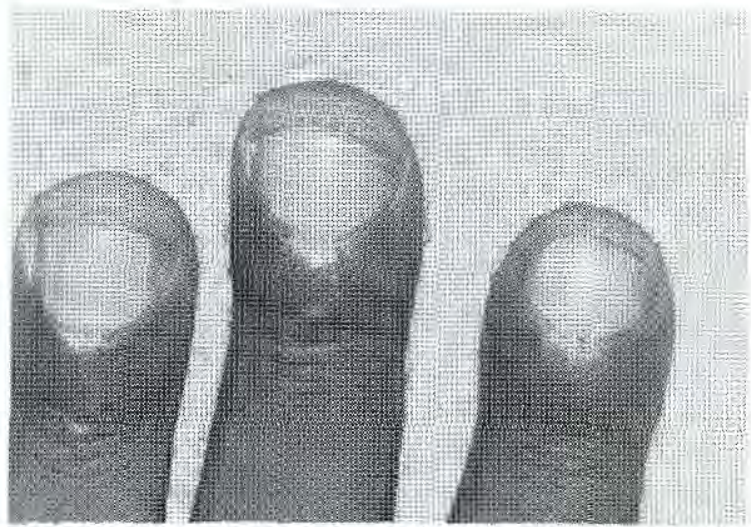

Fig 1. Clubbing with early drum stick formation. Also showing splinter haemorrhages in the proximal nail fold and shiny distal digital skin.

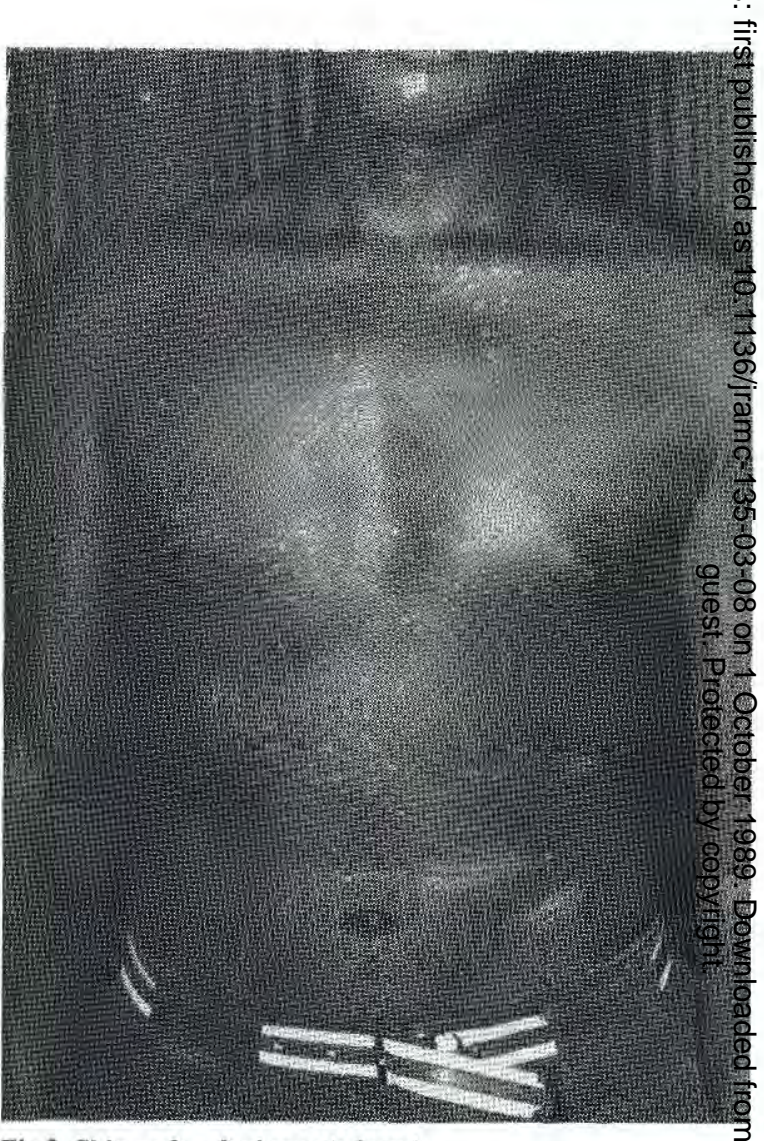

Fig 2. Skin rash - depigmented spots.

no abnormal oesophageal peristalsis. Skin biopsy fror an abdominal wall lesion revealed "sclerosis of dermi collagen with some focal areas of perivasculad infiltration of lymphocytes in the dermis".

Vitalograph: Forced expiratory volume in first secon $3.60 \mathrm{~L}$, forced vital capacity $4.42 \mathrm{~L}, \mathrm{FEV}_{1} / \mathrm{FVC} 81.2 \%$ Peak expiratory flow rate $605 \mathrm{~L} / \mathrm{min}\left(4.33,5.21,82.5 \% \frac{3}{\circ}\right.$. and 643 predicted respectively). Chest $x$-ray reveale $\Phi$ multiple soft tissuc density nodules together witk reticular shadowing in lower zones (compare the two chest radiographs, Figs $3 \& 4$ ).

The following were normal:-

Haemoglobin, white cell count and differential, blood urea, electrolytes, creatinine clearance, mid stream urine, ECG, echocardiogram, serum proteins, liver an 


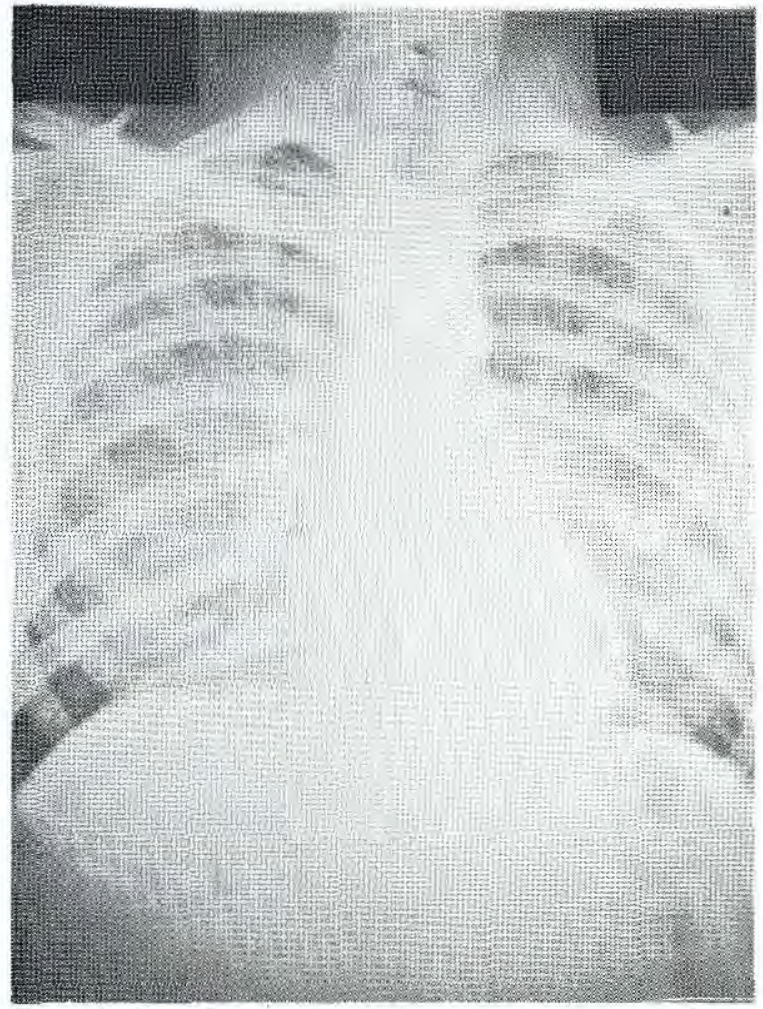

Fig 3. Initial chest X-ray reported as normal.

thyroid function tests, calcium studies, radiological studies - barium meal, enema and $x$-rays of both hands (Fig 5), abdominal ultrasound scan, faecal occult blood negative, and musclc biopsy. Auto-antibodics (double strand anti-DNA, anti-smooth muscle, antimitochondrial and anti-parietal cell antibodies) were all negative.

Extractable nuclear antibodies:-

n RNP (nuclear), SM, SS-A/Ro, SS-B/La, Jo-1, rRNP (ribosomal), PCNA, Ku, SL, PL-4, Pm-ScL, PL-7 and PL12 were all negative.

\section{Discussion}

A diagnosis of clubbing ${ }^{1}$ should be considered with a combination of the following ${ }^{1,2}$.

1. A bulbous, fusiform enlargement of the distal portion of the fingers and toes.

2 . The angle made by the proximal nail fold and the nail plate (Lovibond's angle) ${ }^{3}$ exceeds 180 degrees.

3. No abnormality of underlying phalanx.

4. There is a noticeable mobility of the matrix as one pushes down and away from the distal interphalangeal joint.

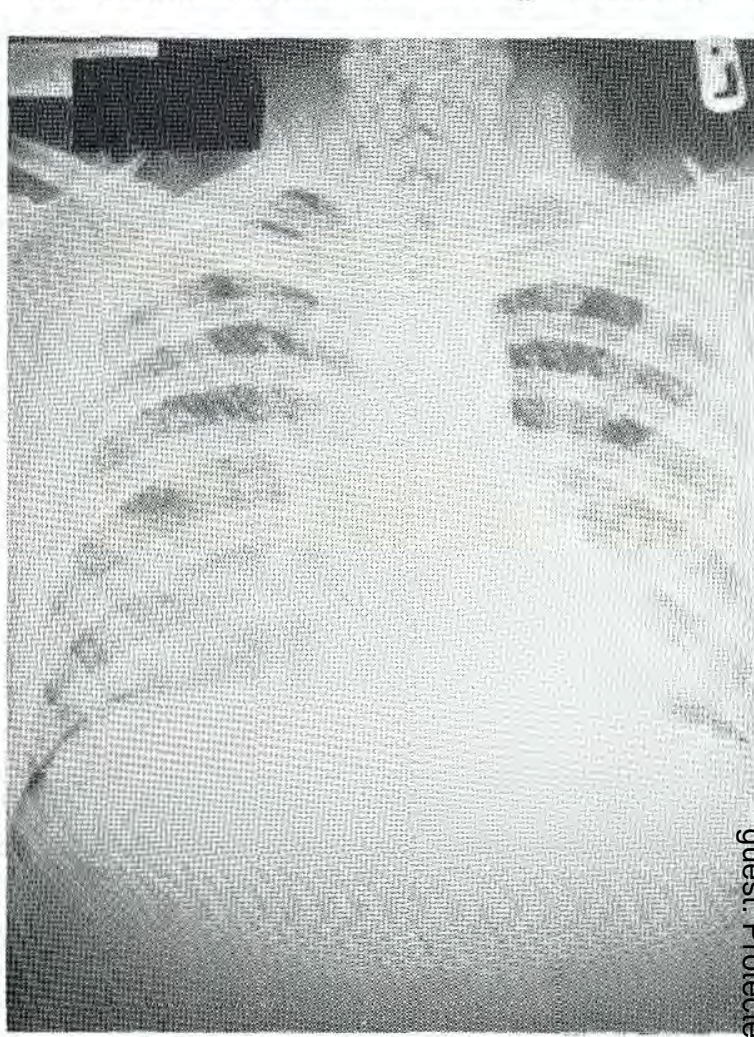

Fig 4. Chest X-ray 2 months later showing mainly basaif distribution of soft tissue nodular and reticular shadowing.

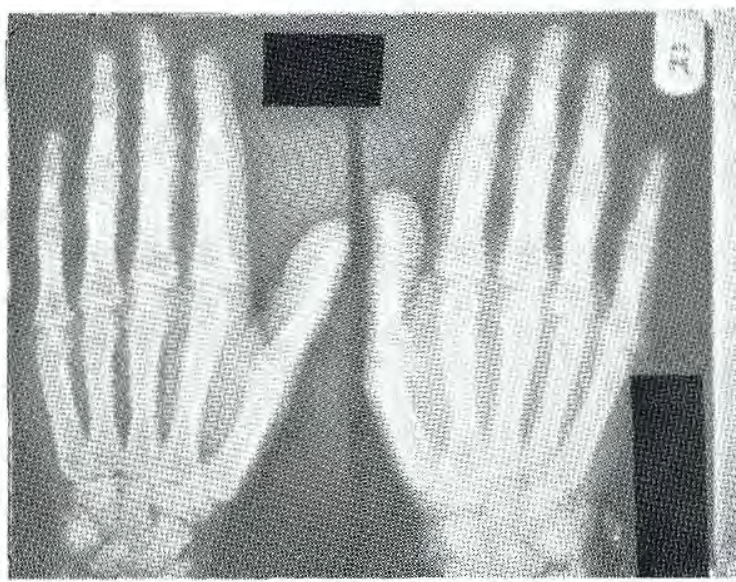

Fig 5. X-ray of hands - no soft tissue calcifications evident.

These criteria were satisfied in this patient, although in systemic sclerosis the degrec of nail changes is surprisingly mild even with distinct changes in the pulp of the fingers'. 
The skin rash in systemic sclerosis is typically described as "one or more round or oval, firm, reddish plaques up to several centimetres in diameter that become white or yellow centrally often with lilac coloured telangiectatic border. A guttate, uncommon variant of morphoea has been described, but its status is tenuous since it may be a variety of Lichen Sclerosis Et Atrophicus." 4

This is characterised by multiple small chalk white lesions primarily involving the anterior chest, neck, shoulders and occasionally other areas of the body ${ }^{4}$.

The skin of the face loses its normal lines, becomes mask-like with telangiectasia, while skin over the fingers (sclerodactyly) shows marked atrophy (shiny tinge) with peri-ungual telangiectasia. Dysphagia occurs in systemic sclerosis in $80 \%$ of cases due to abnormal function of the oesophagus $^{5}$. This man did not have CRST Syndrome ${ }^{6}$ (calcinosis cutis, Raynaud's phenomenon, sclerodactyly and telangiectasia) which is a variant of systemic sclerosis. Basal lung fibrosis on chest radiology is typical, but basal noduies have been associated with other autoimmune diseases that form the spectrum, yet histology and immunology were typical of scleroderma ${ }^{6}$. The fact that he has Sct-70 antibodies confirms the diagnosis ${ }^{7,8}$.

I am grateful to Colonel G O Cowan OBE, FRCP, for his advice on manuscript and $\mathrm{Mr} \mathrm{M}$ Blades, Senior Microbiologist, RAM College, Millbank for the immunological results.
REFERENCES

1. Eiser A Z, Uitto J J and Bauer E A. In Dermatology General Medicine Textbook and Atlas, Third Editie McGraw-Hill Book Co. UK. 1987. 1841.

2. BIGLER F. The morphology of clubbing. Am J Pathol 1958 34: 237.

3. LoviBOND J L. Diagnosis of clubbed fingers. Lancet 198 ; 1: 363 .

4. FitzPatrick T B and Hays H A. In Harrison's Principtes of Internal Medicine, 10th Edition. McGraw-Hill Bo承 Co. NY. 1983. 261.

5. Byron M A and Hughes G V R. In Oxford Textbookg Medicine, First Edition, Oxford University Press, 19 16,33 .

6. Scleroderma or Sclerodermas, leading article. $\mathrm{Br} M e$ 而 $J$ 1973; iii: 249-50.

7. TAN E M. Autoantibodies to nuclear antigens (ANA) Their Immunobiology and Medicine. Adv Immund 1982;33: 167-240.

8. Bernstein R M, Bunn C C and Hughes G V R. Celluter Protein and RNA Antigens in Autoimmune Disease. $M R$ Biol Med. Academic Press Inc. (London) 1984. 2.

\section{PRINTS OF FALKLAND ISLANDS PAINTINGS}

The Royal Army Medical Corps recently commissioned two paintings of RAMC in action during the Falklands Campaign. One depicts an evening battle at Mount Longdon and the other is of a Surgical Team at Ajax Bay.

Limited edition copies of both of these prints are available at the cost of $£ 8$ each, from Regimental Headquarters RAMC, Keogh Barracks, Ash Vale, Nr Aldershot, Hants. Cheques should be made payable to RAMC Corps Mess Funds. 